\title{
Systematic Studies on the Catfishes of Sasthamcottah Lake of Kerala, India
}

\author{
Mathews Plamoottil \\ Asst. Professor in Zoology, Baby John Memorial Government College, \\ Chavara, Kollam, Kerala, India \\ mathewsplamoottil@gmail.com
}

\begin{abstract}
The present study was conducted to analyze the systematic aspects of catfishes occurring in the Sasthamcottah Lake of Kerala, India. Preliminary taxonomic studies were conducted on the fishes of the genera Horabagrus, Mystus, Wallago, Ompok, Clarias and Heteropneustes. The fishes were examined for meristic counts and metric characters. Studies were also conducted on the diversity and classification of these fishes.
\end{abstract}

Keywords: Freshwater fishes, Taxonomy, Bagrids, Cyprinids

Abbreviations: BDD-Body depth at dorsal fin origin; HD-Head depth at occiput, HW-Head width; PRDPre dorsal length; POD-Post dorsal length; LRD-Length of rayed dorsal fin; LCP- Length of caudal peduncle; DCP-Depth of caudal peduncle; LBRD- Length of base of dorsal fin; LBA- Length of base of anal fin; HD-Head depth; HW- Head width; ED-Eye diameter; STL-Snout length; IOW-Inter orbital width; WGM- Width of gape of mouth.

\section{INTRODUCTION}

Catfishes constitute a large group of chiefly freshwater fishes distributed around the world. Africa, India and South America are rich in quantity and species diversity of catfishes. Rita, Sperata, Mystus, Hemibagrus, Horabagrus, Rama, Chandramara, Ompok, Wallago, Pseudotropius and Batasio are the major catfish genera found in India [1 - 4]; of these Mystus, Hemibagrus, Horabagrus, Ompok, Wallago, Pseudotropius and Batasio are the main cat fishes known from inland water bodies of Kerala.

Many Indian and foreign scientists conducted relevant taxonomic studies on the catfishes of India, especially of Kerala. Cuvier and Valenciennes, Hamilton- Buchanan [5, 6], McClelland [7], Jerdon [8] and Guenther [9- 11] are some of them. Dr. Francis Day described many catfishes in his 'The fishes of Malabar' [12], 'the fishes of India' [13] and 'Fauna of British India' [14]. Hora [15- 20] discovered and described many freshwater catfishes. Misra [1] published a reference text on catfish fauna of India. Works of Jayaram [21, 22], Menon [23], Kottelat, Pethiyagoda, Ng and Remadevi [24] are also worth mentioning. Jerdon [8] discovered, named and described Mystus malabaricus and M. montanus from northern parts of Kerala. Day [12] described Mystus armatus from Trichur. Jayaram $[3,4,22]$ conducted serious research works on the cat fishes of India; his revision of genus Mystus is a valuable research book. Recently Plamoottil \& Abraham (2012, 2013a, 2013b, 2013c, 2014a, 2014b) and Plamoottil (2015, 2016) discovered, described and named 7 new catfishes, viz. Glyptothorax elankadensis, Horabagrus melanosoma, Mystus keralai, M. indicus, M. menoni, M. heoki M. catapogon and Batasio flavus

No relevant taxonomic works conducted on the catfishes of Sasthamkotta Lake of Kerala; even though a few surveys conducted on the fish fauna of the Lake, no serious attention was given to the taxonomy of the catfishes in it. It is an endeavor to study some taxonomic aspects of some catfishes of the Lake.

\section{MATERIALS AND MethodS}

Fish collection: Different types of nets are employed for fish collection. Dip nets, Gill nets and Caste nets were used for this purpose. Gill nets are used in areas where water body is deep. Cast nets were used in areas where water is not very deep; it is to catch surface dwellers and shallow water species. Dip nets with a very fine mesh size of 1.5- $2.0 \mathrm{~mm}$ fitted in a frame of 50- $70 \mathrm{x} 40-50 \mathrm{~cm}$ are used for collecting bottom dwelling fishes and also those found among dense aquatic vegetation. 


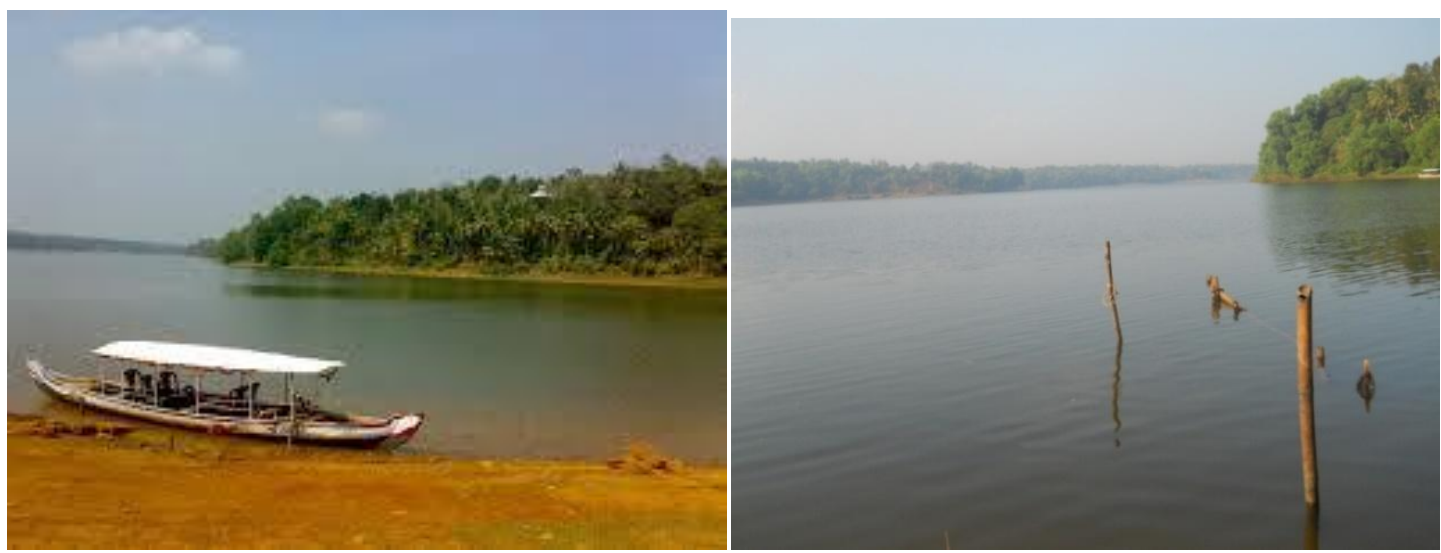

Fig1. \& Fig2. Sasthamkotta Lake

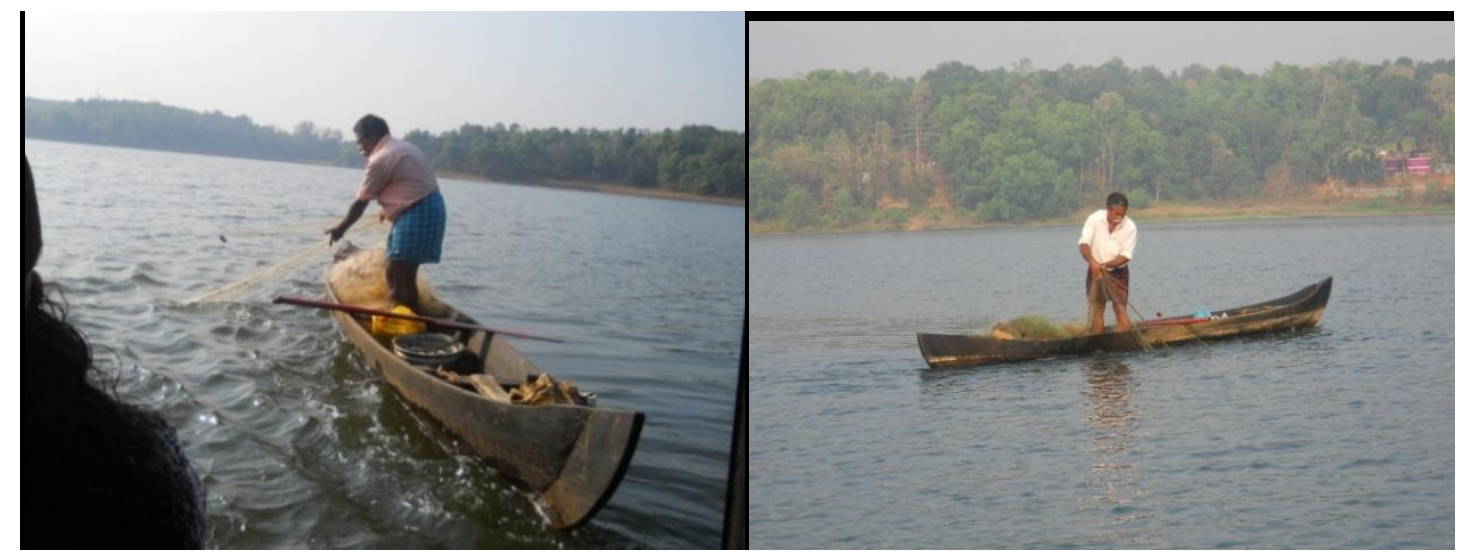

Fig3. Spreading Gill Net in the Lake

Fig4. Hauling the Net

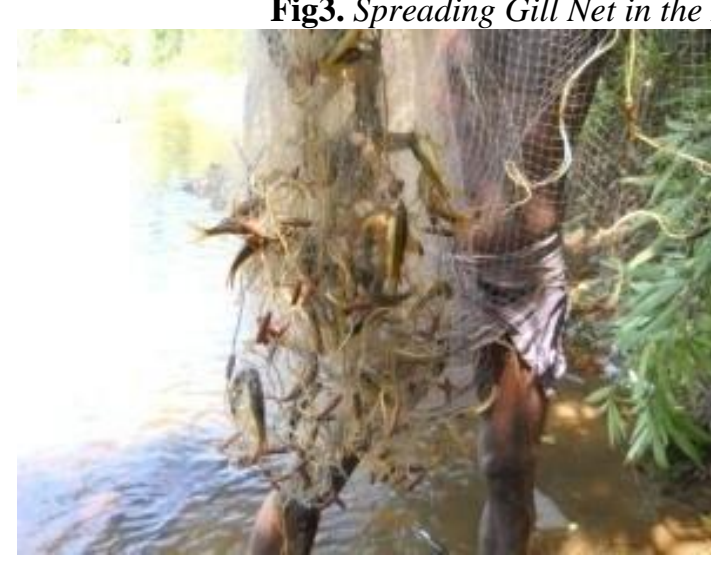

Fig5. Gill Net with Entangled Fishes

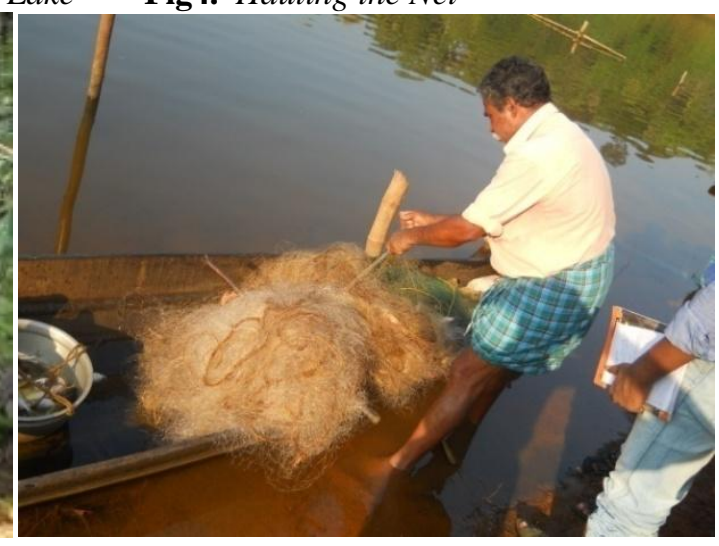

Fig6. Collecting Entangled Fishes from the Net

Fish preservation: Nine percent formalin was used as preservative. Smaller specimens (less than 10 $\mathrm{cm}$ long) were directly put in formalin solution, while medium sized $(10-30 \mathrm{~cm}$ long), prior to the fixation be given a longitudinal incision along the abdomen, without injuring the alimentary canal. Large forms (fishes longer than $30 \mathrm{cms}$ ), be injected ten percent formalin in to the muscle and the abdomen; where the abdomen is not rounded but with a keel, the incision was made on the left side of the fish.

Fish identification: Authentic taxonomic text books were used for identification of fishes. Scientific identification is based mainly on meristic, morphometric and descriptive characters. Meristic counts: The accurate enumeration or counts of scales, fin rays, serration, color bands are of taxonomical importance. The meristic characters are number of any important body character. Fin ray counts: All the fins in bony fishes have long mobile filament like prolongations called rays. Their number is mostly same in the fishes of a species. Therefore fin ray count is very important in fish taxonomy in the identification of fishes. In the case of small fishes fin ray count is taken using a magnifying lens.

Morphometric characters: Morphometric characters are those which can be measured. The measurement of a part of body is worked out as percentage of the measurement of the other parts of the body or of percentage of head length or standard and total length of the body. 
Head length, standard length and total length are mentioned in mm length and measurement of other parts of body is counted as measurements in percentage of head length and standard length.

Methods for studying taxonomic accounts of species: For confirming the identification and proving the identity of fishes collected, detailed description of a species is necessary. Meristic characters such as fin ray counts, position of eyes, fins, shape of mouth, lips etc were all taken in detail. Various body measurements were taken from many similar specimens.

\section{RESULT AND DISCUSSION}

\subsection{Diversity of Catfishes}

During this study seven catfishes were collected from various locations of Sasthamkottah Lake. Horabagrus brachysoma, Mystus oculatus, Ompok malabaricus O. bimaculatus, Wallago attu, Clarias dussumieri and Heteropneustes fossilis were the catfishes collected from this Lake. They are included in the order Siluriformes and families Bagridae, Siluridae, Clariidae and Heteropneustidae. All the above fishes were originally described by foreign scientists and type localities of all, except Heteropneustes fossilis, were different regions of Kerala. Most of them have different synonyms, common names and local names. Details of catfishes of Sasthamkottah Lake are shown in Table $1 \&$ 2.

Some fishes exhibited different colorations in different seasons. All the catfishes of the Sasthamkottah Lake are edible and popular food fishes. Some of them are also used as ornamental fishes. Horabagrus brachysoma and Wallago attu are commercially important fishes of the Lake. Clarias dussumieri and Heteropneustes fossilis are most palatable food fishes of the water body; but it was understood from the local inhabitants that population of these fishes have been greatly declined due to pollution and irresponsible fishing practices.

Table1. Author, Locality and Classification of Catfishes of Sasthamkottah Lake

\begin{tabular}{|l|l|l|l|l|l|}
\hline $\begin{array}{l}\text { Sl. } \\
\text { No }\end{array}$ & Name of fish & Author & $\begin{array}{l}\text { Type } \\
\text { locality }\end{array}$ & Order & Family \\
\hline 1 & Horabagrus brachysoma & Guenther & Cochin & Siluriformes & Bagridae \\
\hline 2 & Mystus oculatus & Valenciennes & $\begin{array}{l}\text { Kuttiadi } \\
\text { Malabar }\end{array}$ & Siluriformes & Bagridae \\
\hline 3 & Ompok malabaricus & Valenciennes & Malabar & Siluriformes & Siluridae \\
\hline 4 & Ompok bimaculatus & Bloch & Malabar & Siluriformes & Siluridae \\
\hline 5 & Wallago attu & Bloch \& Schneider & Malabar & Siluriformes & Siluridae \\
\hline 6 & Clarias dussumieri & Valenciennes & $\begin{array}{l}\text { Pondicherry } \\
\text { and Malabar }\end{array}$ & Siluriformes & Clariidae \\
\hline 7 & Heteropneustes fossilis & Bloch & Tranquebar & Siluriformes & Heteropneustidae \\
\hline
\end{tabular}

Table2. Names, Significance and IUCN Status of Cat Fishes of Sasthamkottah Lake

\begin{tabular}{|c|c|c|c|c|c|c|}
\hline $\begin{array}{l}\text { Sl. } \\
\text { No }\end{array}$ & Name of fish & Synonyms & $\begin{array}{l}\text { Common name/Trade } \\
\text { name }\end{array}$ & $\begin{array}{l}\text { Local name } \\
\text { (Malayalam) }\end{array}$ & Significance & $\begin{array}{l}\text { IUCN } \\
\text { Status }\end{array}$ \\
\hline 1 & $\begin{array}{l}\text { Horabagrus } \\
\text { brachysoma }\end{array}$ & $\begin{array}{l}\text { Pseudobagrus } \\
\text { brachysoma, } \\
\text { Pseudobagrus } \\
\text { chryseus, } \\
\text { Macrones chryseus }\end{array}$ & Gunther's cat fish & $\begin{array}{l}\text { Mungiletta } \\
\text { Manjetta } \\
\text { Moongil, } \\
\text { Manjakkoori }\end{array}$ & F.F, OF & $\mathrm{EN}$ \\
\hline 2 & Mystus oculatus & $\begin{array}{l}\text { Bagrus oculatus, } \\
\text { Macrones oculatus }\end{array}$ & Malabar Mystus & Chillan & $\mathrm{FF}, \mathrm{OF}$ & LRLC \\
\hline 3 & $\begin{array}{l}\text { Ompok } \\
\text { malabaricus }\end{array}$ & \begin{tabular}{|l} 
Silurus \\
malabaricus, \\
Callichrous \\
malabaricus, \\
Silurus goae
\end{tabular} & Goan cat fish & $\begin{array}{l}\text { Manklan, } \\
\text { Thonnavaala, } \\
\text { Manjavala, } \\
\text { Chotta vala, } \\
\text { Pottu vaala, } \\
\text { Pullu vaala, } \\
\text { Klappa, } \\
\text { Dhalaman }\end{array}$ & FF,OF & CR \\
\hline 4 & $\begin{array}{l}\text { Ompok } \\
\text { bimaculatus }\end{array}$ & \begin{tabular}{|l} 
Silurus bimaculatus \\
Callichrous
\end{tabular} & Indian butter cat fish & $\begin{array}{l}\text { Chotta vala, } \\
\text { Pottu vaala, }\end{array}$ & $\mathrm{FF}, \mathrm{OF}$ & $\mathrm{EN}$ \\
\hline
\end{tabular}




\begin{tabular}{|c|c|c|c|c|c|c|}
\hline & & $\begin{array}{l}\text { bimaculatus } \\
\text { Callichrous } \\
\text { macrophthalmus } \\
\text { Ompok canio } \\
\text { Ompok sindensis }\end{array}$ & & $\begin{array}{l}\text { Pulluvala, } \\
\text { Dhalaman }\end{array}$ & & \\
\hline 5 & Wallago attu & $\begin{array}{l}\text { Silurus attu } \\
\text { Wallagonia attu } \\
\text { W. attu valeya }\end{array}$ & $\begin{array}{l}\text { Boal, } \\
\text { Fresh water shark, } \\
\text { Shark cat fish, } \\
\text { Killer shark }\end{array}$ & $\begin{array}{l}\text { Vaala, } \\
\text { Aattu vala, }\end{array}$ & FF & LRNT \\
\hline 6 & $\begin{array}{l}\text { Clarias } \\
\text { dussumieri }\end{array}$ & Nil & Valenciennes' clariid & $\begin{array}{l}\text { Naadan musi, } \\
\text { Musi, } \\
\text { Muzzu }\end{array}$ & FF & VU \\
\hline 7 & $\begin{array}{l}\text { Heteropneustes } \\
\text { fossilis }\end{array}$ & $\begin{array}{l}\text { Silurus fossilis } \\
\text { Sacchobranchus } \\
\text { fossilis }\end{array}$ & Stinging cat fish & $\begin{array}{l}\text { Kaari, } \\
\text { Kaarimeen, } \\
\text { Moyya, } \\
\text { Kadu, } \\
\text { Kaduku -meen }\end{array}$ & FF & EN \\
\hline
\end{tabular}

Taxonomic accounts of species: Conservation efforts require scientific documentation of the bioresources along with details on their distribution and status (Easa \& Shaji, 2003). This requires inventory and systematic studies of the fishes. A detailed study on the different aspects of taxonomy of freshwater fishes is helpful in the correct identification and to search for the presence of new species. So an effort was taken to study some taxonomic details of catfishes of Sasthamkottah Lake.

This study was based on examination of freshly collected catfish species from Sasthamkottah Lake. In this context the Lake was visited and collected all types of catfishes. Color of fishes in live and formalin preserved conditions was noted and photographed. Measurements and counts used are as per Jayaram $[3,4,22]$.

\subsection{Horabagrus brachysoma (Guenther)}

Pseudobagrus brachysoma Guenther, 1864, Cat. Fish. Brit. Mus. 5: 86 (type locality: "Cochin China" lapsus calami for Cochin).

Diagnosis: Occipital process extends to pre dorsal plate; mouth sub terminal; a large round blotch present at the branchial region. Maxillary barbels extend to pectoral fin base; rayed dorsal fin with a strong, feebly serrated spine; adipose dorsal fin is short and low.

Meristic charaters: D- I, 6-7; P- I, 8-9; V- I, 5; A- III, 20- 25. C- 17.

Metric characters: \% SL: HL- 28.0; HD- 17.1; HW- 21.0; BDD- 22.0; PRD- 37.3; POD- 61.0; PRP23.8; PRA- 63.8; PRPL- 52.7; LRD- 20.0; LBRD- 9.1; LBAD- 4.4; LBA- 24.0; DCP- 12.8; LCP12.6; LAD- 7.8; \% HL: HD- 61.8; HW- 73.5; ED- 18.9; IOW- 53.1; INW- 32.3; STL- 40.5; WGM48.7; LMB- 70.2; LNB- 59.2; LOMB- 65.0; LIMB- 47.9.

Other features: Color dark greenish above with golden yellow flanks; dorsal and anal fins yellowish orange; caudal fin yellow; a semi lunar thick black patch present at the caudal fin base.

\subsection{Mystus oculatus (Valenciennes)}

Bagrus oculatus Valenciennes, 1839, IN Cuvier \& Valenciennes Hist. Nat. Poiss. 14: 434 (type locality: Cote de, Malabar).

Diagnosis: Median longitudinal groove on head extends to base of occipital process; occipital process extends to basal bone of dorsal fin; maxillary barbels extend to middle of anal fin; a dark spot is present at the origin of the dorsal fin.

Meristic counts: D- I, 7; A- iii- iv, 8-9; P- I, 6; V- i, 5.

Metric characters: \% SL; BDD- 23.7; HL-23.2; HD-21.6; PRD-38.7; POD-64.6; PRP-50.7; PRA69.7; LD-24.7; LBRD-16.8; LBAD-14.7; LBA-12.9; DCP-10.9; LCP-10.5; LAD- 12.0. \% HL: HD94.0; ED-16.9; IOW- 41.6; STL-30.2.

Other features: Silvery or yellowish on the flanks and darker on the dorsal region; abdomen whitish. Adipose dorsal fin base short; inter dorsal distance about 1.2 times in adipose dorsal fin base. 


\subsection{Ompok malabaricus (Valenciennes)}

Silurus malabaricus Valenciennes IN Cuvier \& Valenciennes, 1839, Hist. Nat. Poiss. 14: 353 (type locality: Malabar).

Diagnosis: Maxillary barbels extend beyond pelvic fin origin; mandibular barbels extending posteriorly no farther than hind border of eye; mouth somewhat oblique and its gape wide; pectoral spine strong, serrated on its inner edge.

Meristic counts: D- I, 3; P- I, 11- 12; V- i, 7; A- iii, $63-69$.

Metric characters: \% SL; HL- 18.5; HD-14.9; HW-11.3; BDD- 19.9; BWD-13.4; BWA- 11.1; PRD27.3; POD-59.5; PRP-20.6; PRPL-33.3; PRA-34.6; LP-11.6; LPL- 5. 2; LC- 11.0; DP-PL-15.2; ED2.3; IOW-9.4; INW-6.6; STL-6.4; WGM-11.7.

Other features: Colour grayish brown shot with purple, which becomes paler yellow; the membrane of fin elements mottled with minute black dots. Teeth in broad villiform bands on jaws medially interrupted; teeth on vomer in two large, crescent- shaped patches, separated from each other by a distance equal to half length of one patch.

\subsection{Ompok bimaculatus (Bloch)}

Silurus bimaculatus Bloch, 1797, Nat. Hist. Poiss. 17 (2) (type locality: Malabar).

Diagnosis: Lower border of eyes on the level of edge of mouth; anal fin not confluent with caudal fin; the latter is forked with round lobes; a black humeral blotch present.

Meristic counts: D- 4; P- I, 9; V- I, 6; A- 64; C-14.

Metric characters: \% SL: HL- 22.8; HD-15.3; HW-12.9; BDD-20.1; PRD-36.3; POD- 68.5; PRP21.2; PRPL- 30.3; PRA- 39.6; LC-13.1; DP- PL-11.3; DPL-A- 9.1; IOW-9.3; STL- 9.2; WGM- 1 1.3 .

Other features: Maxillary barbels extend to the base of pectoral fin; lateral line complete, extending from head to tail; various small grooves present on the ventral region of head. Color grey; a diffused black spot present on the lowest part of pectorals; pelvic fin extend to anal fin origin and a little longer; no space between anal and caudal fin.

\subsection{Wallago attu (Bloch \& Schneider)}

Silurus attu Blotch \& Scheiner, Syst. Ichthyol. 378 (type locality: Malabar).

Diagnosis: Maxillaries extend well beyond origin of anal fin; mouth is oblique and cleft of mouth extends beyond the orbit; pectoral spine weak, poorly serrated on its inner edge.

Meristic counts: D- 5; P- I, 13- 15; V-i, 7- 9; A-iii, 74- 93.

Metric characters: \% SL: HL-21.2; HD-14.3; HW-11.6; BDD-16.2; PRD-27.2; POD-68.6; PRP-20.6; PRPL-33.2; PRA-40.6; LD-14.4; LC-11.3; LBD-1.3; LBA-57. 5; LCP-1.7; DCP-4.2; WCP- 1.4. \% HL: HD- 64.3; HW-54.4; ED-11.3; IOW-44.3; INW-20.2; WGM-47.6

Other features: Caudal fin deeply forked and its upper lobe longer; color pale greenish to yellowish green;

\subsection{Clarias dussumieri Valenciennes}

Clarias dussumieri Valenciennes IN Cuvier \& Valenciennes Hist. Nat. Poiss, 1840, 15: 382 (type locality: Pondicherry and Malabar).

Diagnosis: Head depressed, snout broad; occipital process broadly rounded; anal and dorsal fins are long based. Pectoral fin with a strong spine, which may be serrated on its outer edge, but only a few small teeth present in the middle of its inner margin.

Meristic counts: D- 66- 69; P- I, 10- 14; V- I, 5; A- 45- 59.

Metric characters: \% SL: BDD-15.2; HL-24.3; HD- 12.4; PRD-36.4; POD-77.2; PRP 49.1; LD-4.1; LBAD-60.2; LBA-30.3; LP-12.2; LPL-10.1; LCP-4.3; DCP-7.1.

Other features: Body color dark above, lighter ventrally; dorsal, anal and caudal fins are tinged with red. 


\subsection{Heteropneustes fossilis (Bloch)}

Silurus fossilis, Bloch, 1794, Naturg. Ausland Fische 8; 46 (type locality: Tranquebar).

Diagnosis: Median frontal groove on head limited to a round depression between and backwards of eyes; occipital process short and not extending to base of dorsal fin; pectoral fin with strong serrated spine; rayed dorsal fin is short and without a spine; anal fin long based, separated by a distinct notch from caudal fin.

Meristic counts: D- 6-7; P- I, 7; V- i, 5; A- 60- 70.

Metric characters: \% SL: HL- 19.2; HD-10.2; HW-16.1; BDD-20.2; PRD-32.3; POD-68.3; PRP16.4; POD-68.4; PRP-16.5; PRPL-35.5; PRA-40.1; LD-11.2; LC-14.1; LBD-40.3; LBC-40.3; \% HL: ED-13.8; IOW-48.4; INW-27.5; WGM-38.3.

Other features: Body elongate and sub cylindrical to pelvic base, compressed behind. Dorsal fin located a little in front of pelvic; pectoral never reaches pelvic fin, the latter reach behind anal origin; anal never fused to caudal.

\subsection{Catfishes of Sasthamkottah Lake}
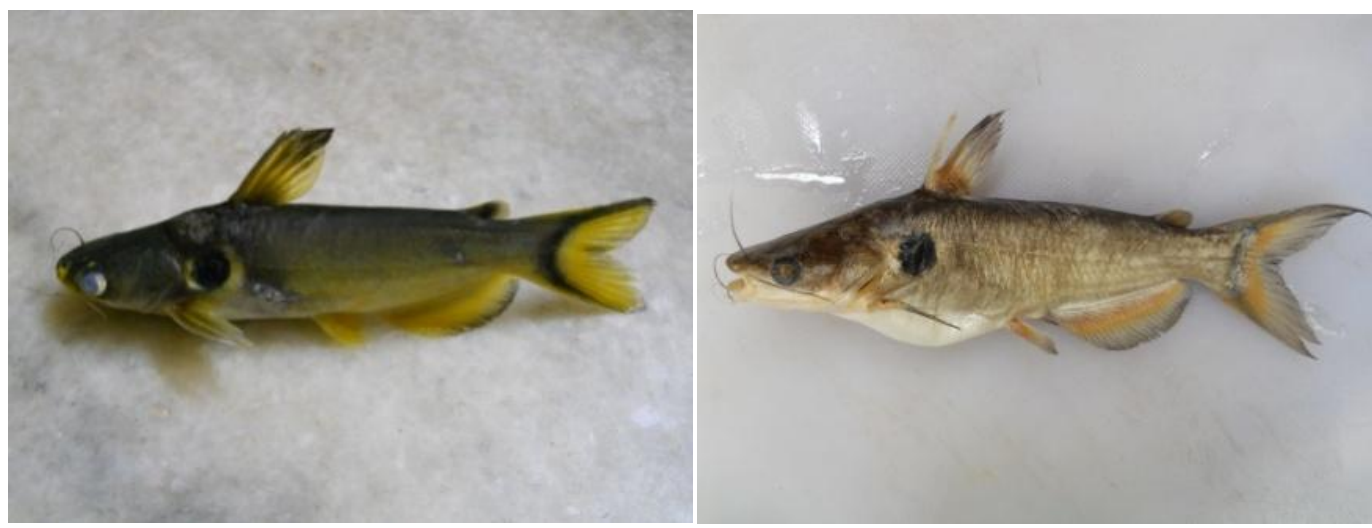

Fig7.\& Fig8. Horabagrus brachysoma- Fresh \& Preserved

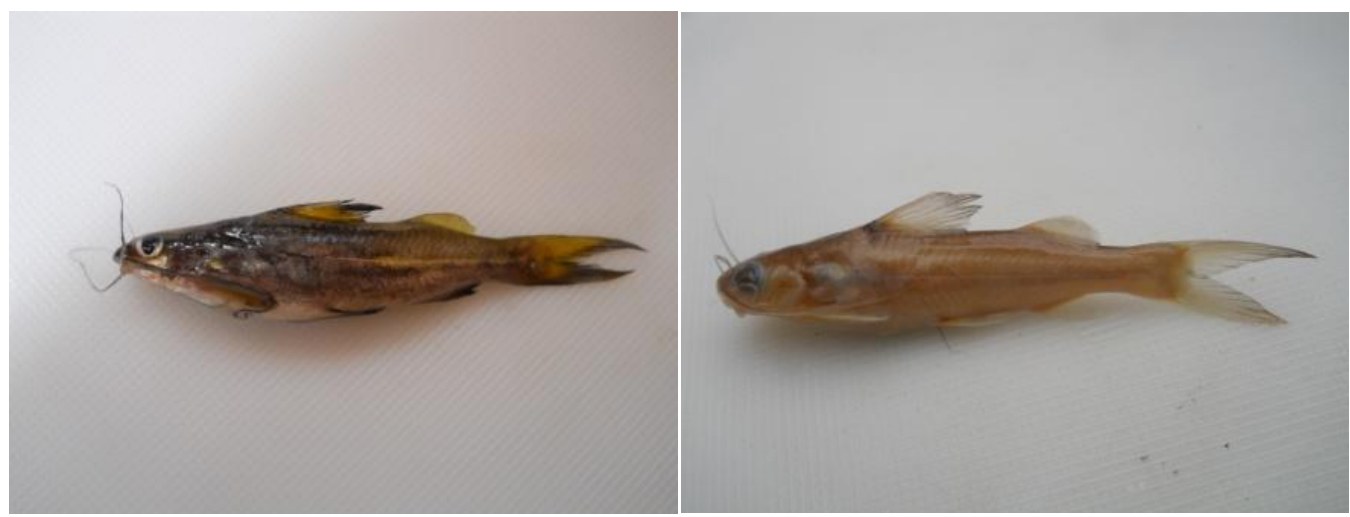

Fig9. \& 10. - Mystus Oculatus - Fresh \& Preserved.

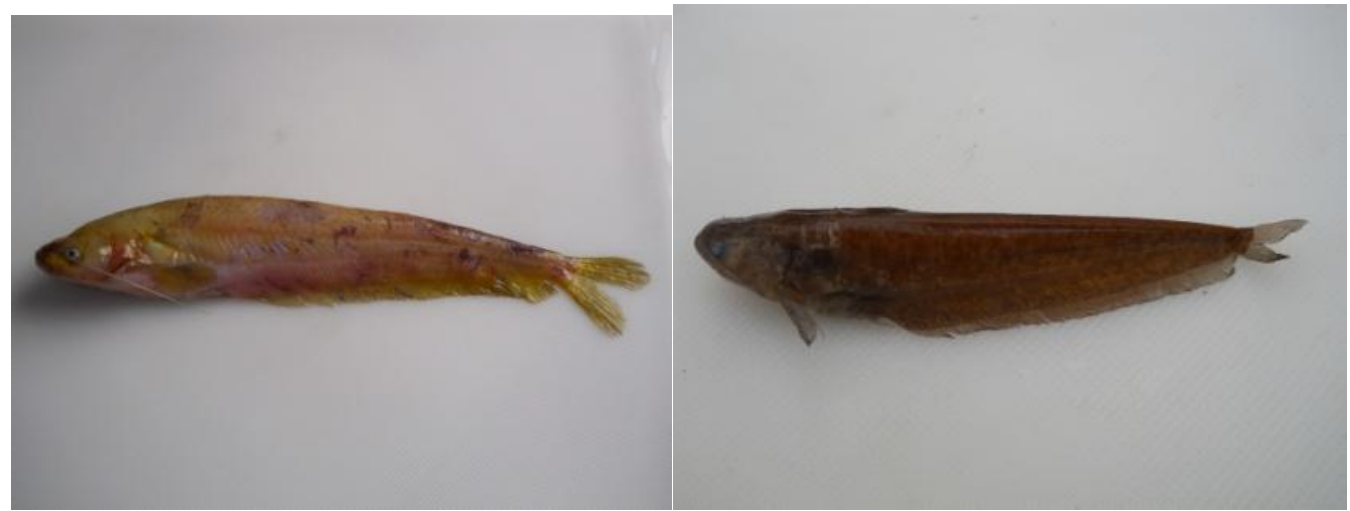

Fig11.- Ompok Malabaricus

Fig12. - O. Bimaculatus 


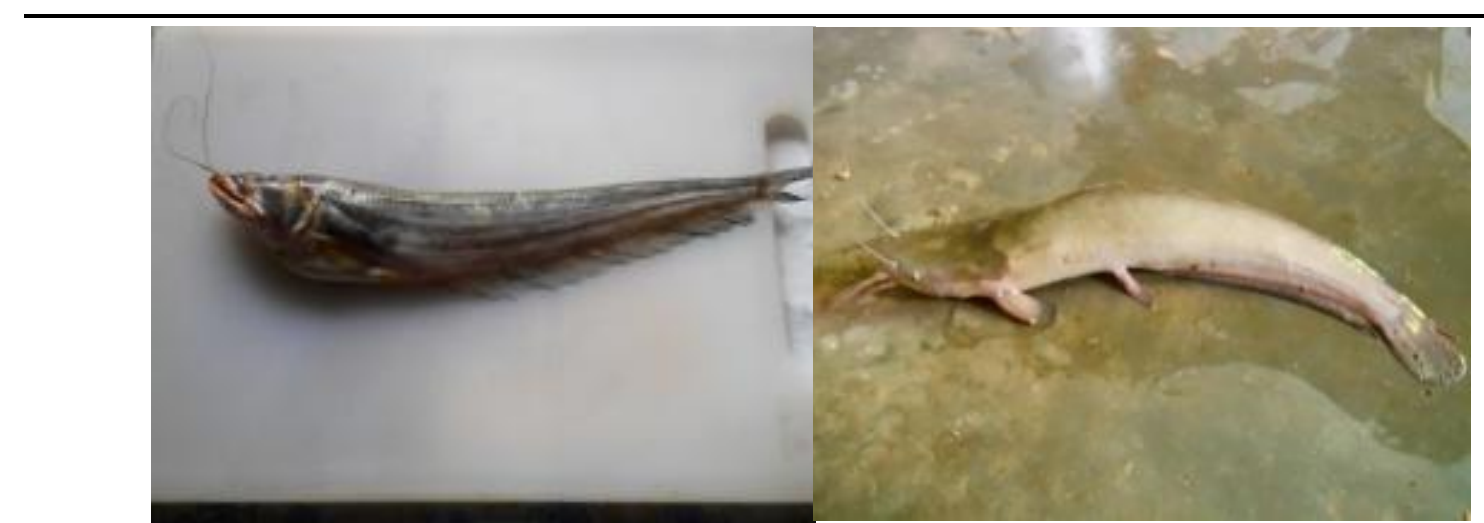

Fig13. -Wallago Attu

Fig14. Clarias Dussumieri

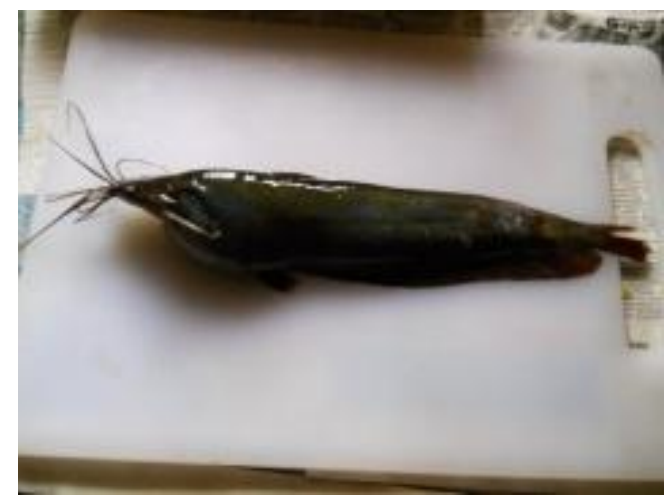

Fig15. Heretopneustes Fossilis

\section{CONClusion}

Kerala is the foremost fish producing State in India. The inland water bodies of Kerala harbor a variety of indigenous fishes. The natural source of ornamental fishes in the water bodies of the state is rich and diversified. The freshwater ornamental fish fauna of the rivers of the Kerala is biologically more diverse, represented by 125 species. Altogether 210 primary fishes are found in the inland waters, of which 53 species are endemic. Today the Western Ghats is recognized as one of the twenty five "biodiversity hotspots" in the world.

Even though a number of research works had been conducted on biology and diversity of fishes of freshwater bodies of Kerala, serious research works concentrated on the taxonomic aspects are very rare. No taxonomic works had been conducted on the fishes of Sasthamkottah Lake. The current work was an endeavor to study the taxonomic aspects of catfishes of the Lake.

Studies on the fishes of Sasthamkottah Lake are relevant; it is because it is a freshwater Lake which is not receiving water from any other sources; there is no possibility of inflow or outflow of water. Due to same reason estuarine species are entirely absent in it. More over the freshwater fishes inhabiting in this water body are native ones and not migrated from any other regions. So the taxonomic studies on these fishes are relevant. It is expected that more serious and detailed taxonomic studies will be conducted on the fishes of Sasthamkottah Lake.

\section{ACKNOWLEDGEMENT}

The author acknowledges Principal, Baby John Memorial Government College, Chavara, Kollam, Kerala for facilities provided to carry out this research work. I am grateful to anonymous reviewers for comments that helped to improve the manuscript.

\section{REFERENCES}

[1] Misra, K. S. 1976. The fauna of India and adjacent countries: Cleupeiformes, Bathycleupiformes, Galaxyformes, Scopoliformes, and Ateloopiformes, Zoological Survey of India, 438p.

[2] Talwar, P. K. \& A. Jhingran 1991. Inland fishes of India and adjacent countries. Oxford and IBH publishing Co., New Delhi, 1158p.

[3] Jayaram, K. C. \& A. Sanyal. 2003. A taxonomic revision of the fishes of the genus Mystus Scopeli. Records of Zoological Survey of India, Occational Paper No. 207. 136. 
[4] Jayaram, K. C. 2006. Cat fishes of India, Narendra Publishing House, Delhi, 41- 145.

[5] Buchanan, H. 1822. An account of the fishes found in the River Ganges and its branches. Edinburg, London, 185, 378.

[6] Buchanan, H. 1877. Journey from Madras through the countries of Mysore, Canara and Malabar, I: vii- xii, 420 pages.

[7] M'Clelland, J. 1839. Indian Cyprinidae. Asiatic Researchers, Culcutta, Bishop College, Press, 217- 268.

[8] Jerdon, T. C. 1849. The fishes of Southern India. Madras Journal of Literature and Science xv, p.147.

[9] Gunther, A. 1861. Catalogue of the fishes in the British Museum. London, 3, 542p.

[10] Gunther, A. 1864. Catalogue of fishes in the British Museum, London, 5: 86.

[11] Gunther, A. 1868. Catalogue of the fishes in the British Museum. London, pp. 113-114

[12] Day, F. 1865a. The Fishes of Malabar. Bernard Quaritch, London, 185.

[13] Day, F. 1878. The fishes of India: being a natural history of the fishes known to inhabit the seas and fresh waters of India, Burma, and Ceylon. Bernard Quaritch, Piccadilly, London 443.

[14] Day, F. 1889. Fauna of British India including Ceylon and Burma. Volume I, Taylor and Francis, London, 1:148.

[15] Hora, S. L. 1920. Indian Homalopteridae. Records of Indian Museum. XIX: 203- 205.

[16] Hora, S. L. 1923. On the composite genus Glyptosternum McClelland. Records of Indian Museum, 25:14.

[17] Hora, S. L. 1936. Siluroid fishes of India, Burma and Ceylon. Records of Indian Museum, 38 (2): 199- 202.

[18] Hora, S. L. 1941. Homalopterid fishes from Peninsular India.. Records of Indian Museum. 43 (2): 221- 232.

[19] Jayaram, K. C. 2010. Fresh water fishes of the Indian region. Narendra publishing House, Delhi 292.

[20] Menon, A. G. K. 1999. Check list of fresh water fishes of India. Records of Zoological Survey of India, Occasional Paper 175: 212.

[21] Remadevi, K. 1992. Fishes of Kalakad Wild Life Sanctuary, Thirunelveli district, Tamil Nadu with redescription of Horalabiosa joshuai Silas. Records of Zoological Survey of India, 92: 193209.

[22] Plamoottil, N. P \& Abraham N. P 2012. Glyptothorax elankadensis, a new species of sisorid fish from Manimala River, Kerala, India. Biosystematica, 6 (2): 17- 25.

[23] Plamoottil, M \& Abraham, N. P. 2013a. Mystus menoni, a new fish species from Kerala, India. International Journal of Pure and Applied Zoology, 2013, 1(4): 315-325.

[24] Plamoottil, M \& Abraham, N.P. 2013b. Mystus indicus and M. heoki, two new cat fishes from Kerala, India. Biosystematica, 2013, 7(1): 43-58.

[25] Plamoottil, M \& Abraham, N. P. 2013c. Horabagrus melanosoma, a new fish species (Actinopterygii: Siluriformes) from Kerala, India, International Journal of Pure and Applied Zoology, 1 (4): 280-288.

[26] Plamoottil, M. \& Abraham, N. P. 2014a. Mystus keralai, a new fish species from Kerala, India, International Journal of Pure and Applied Zoology, 2 (3): 231- 240.

[27] Plamoottil, M \& Abraham, N. P. 2014b. Rediscovery and redescription of Mystus armatus Day. International Journal of Research in Fisheries and Aquaculture, 2014; 4(1): 18-21.

[28] Plamoottil, M. 2015. Batasio flavus, a new catfish (Siluriformes: Bagridae) species from Kerala, India. Journal of Research in Biology, 5 (5): 1799-1808. 